\title{
Aplikasi kebugaran dan kesehatan berbasis android: Bagaimana persepsi dan minat masyarakat?
}

\author{
Muhammad Sigit Antoni *, S. Suharjana \\ Program Studi Ilmu Keolahragaan, Program Pascasarjana, Universitas Negeri Yogyakarta. \\ Jalan Colombo No. 1, Karangmalang, Yogyakarta, 55281, Indonesia \\ * Corresponding Author. E-mail: sigitantoni@gmail.com \\ Received: 13 October 2018; Revised: 23 October 2018; Accepted: 31 October 2018
}

\begin{abstract}
Abstrak
Tujuan penelitian ini adalah untuk memberikan gambaran tentang persepsi dan minat masyarakat olahraga di Daerah Istimewa Yogyakarta terhadap aplikasi android kategori kebugaran dan kesehatan. Penelitian ini merupakan penelitian deskriptif dengan metode survei. Instrumen yang digunakan dalam penelitian ini adalah angket berbasis web. Penelitian dilakukan dengan melakukan survei terhadap para praktisi keolahragaan, akademisi di bidang olahraga kesehatan, serta masyarakat umum yang berjumlah 62 responden. Hasil penelitian menunjukkan bahwa persepsi responden terhadap aplikasi ponsel pintar sistem operasi android kategori kesehatan dan kebugaran pada kategori Baik Sekali sebesar 4,8\%, Baik sebesar $37,2 \%$, Cukup sebesar 22,6\%, Kurang sebesar 30,6\%, dan Sangat Kurang sebesar 4,8\%. Minat responden terhadap aplikasi ponsel pintar sistem operasi android kategori kesehatan dan kebugaran pada kategori Baik Sekali sebesar 12,9\%, Baik sebesar 43,6\%, Cukup sebesar 29\%, Kurang sebesar 11,3\%, dan Sangat Kurang sebesar $3,2 \%$. Secara umum, hasil penelitian menunjukkan bahwa persepsi dan minat para praktisi keolahragaan, akademisi di bidang olahraga kesehatan, serta masyarakat umum terhadap aplikasi ponsel pintar sistem operasi android kategori kesehatan dan kebugaran adalah baik.
\end{abstract}

Kata Kunci: aplikasi, android, persepsi, minat, kebugaran dan kesehatan

\section{Android application in sport and health: How are society's perception and interest?}

\begin{abstract}
The aim of this research was to identify society's perception and interest of sport and health android application. This was a descriptive research with survey method using web based questionare as the research instruments. The research had surveyed sport health professionals, sport health academicians, and the citizens. The number of the subject were 62 respondents. The result of this research showed that society's perception of sport and health android application was rated Very Good (4,8\%), Good (37,2\%), Good Enough (22,6\%), Mildly Good (30,6\%), and Not Good (4,8\%). Society's interest of sport and health android application was rated Very Good (12,9\%), Good (43,6\%), Good Enough (29\%), Mildly Good (11,3\%), and Not Good (3,2\%). In general, the results of the study showed that the perceptions and interests of sport health professionals, sport health academicians, and the citizens of sport and health android application is good. Keywords: technology, android application, sport and health.
\end{abstract}

How to Cite: Antoni, M., \& Suharjana, S. (2019). Aplikasi kebugaran dan kesehatan berbasis android: Bagaimana persepsi dan minat masyarakat?. Jurnal Keolahragaan, 7(1), 34-42. doi:https://doi.org/10.21831/jk.v7i1.21571

doi https://doi.org/10.21831/jk.v7i1.21571

\section{PENDAHULUAN}

Perkembangan teknologi serta kemajuan ilmu pegetahuan dan teknologi (Iptek) dewasa ini telah berkembang sangat pesat, salah satunya adalah perkembangan posel pintar (smartphone). The Mobile World (Rao \& Krishna, 2014, p. 20) menyatakan bahwa pada tahun 2014, penggunaan perangkat smartphone di dunia mencapai 4,25 miliar unit. Hal tersebut berarti setengah dari populasi yang ada di dunia menggunakan smartphone. Masyarakat Indonesia juga turut menyambut perkembangan teknologi smartphone. Pada tahun 2015, Indonesia berada pada urutan ke-tiga pengguna smartphone terbanyak di Asia Pasifik (Indonesia Investments, 2016). 
Perangkat smartphone yang beredar menggunakan berbagai sistem operasi, diantaranya iOS, Blackberry OS, Android OS, dan Windows. Di Indonesia, sistem operasi Android merupakan sistem operasi yang paling banyak digunakan oleh pengguna smartphone. Disebutkan bahwa pada bulan Juli 2016, pengguna ponsel di Indonesia dengan sistem operasi android mencapai 73,8\% dari keseluruhan jumlah pengguna smartphone di Indonesia (Statista, 2017). Berbagai keunggulan sistem operasi android menjadikan smartphone dengan sistem operasi android menjadi pilihan bagi para pengguna smartphone di Indonesia.

Seiring dengan dinamika dalam kehidupan sehari-hari, kesehatan dan kebugaran telah menjadi kebutuhan penting bagi manusia. Berbagai macam teknologi dikembangkan untuk mendukung berbagai kemudahan dalam hal kesehatan dan kebugaran, salah satunya adalah android. Android merupakan sebuah sistem operasi yang berbasis Linux dan dikembangkan secara khusus bagi ponsel pintar (smartphone) maupun komputer tablet dengan perangkat layar sentuh. Sistem operasi Android pertama kali dikembangkan oleh Android, Inc. pada bulan Oktober 2003 di California, dan diambil alih oleh Google pada tahun 2005.

Android saat ini telah menjadi sistem operasi yang paling banyak digunakan dan menjadi sistem operasi mobile yang mendapatkan penjualan paling tinggi. Sebagai salah satu sistem operasi yang paling banyak digunakan pada ponsel pintar (smartphone) mempunyai beberapa kelebihan (Safaat, 2014), diantaranya: Pertama, Basis pengguna Android yang besar, khususnya pada negara-negara berkembang. Hal tersebut memberikan peluang pasar yang terbuka secara luas bagi para pengembang. Kedua, Android memiliki komponen perangkat lunak yang baik serta memperoleh dukungan aplikasi. Hal tersebut memungkinkan pengguna dapat secara leluasa mengeksplorasi berbagai aplikasi dalam perangkat ponselnya. Ketiga, Pengguna dapat mengakses banyak aplikasi melalui gudang aplikasi. Androdi Google sebagai gudang aplikasi Android dapat diakses secara mudah. Terdapat ribuan aplikasi yang dapat diakses, dan diunduh baik secara gratis maupun berbayar di dalam gudang aplikasi Android Google. Keempat, Perangkat dengan sistem operasi Android memungkinkan pengguna untuk menjalankan berbagai macam aplikasi secara bersamaan. Dengan didukung sistem multi-tasking, pengguna perangkat dengan sistem operasi Android dapat menelusuri internet, mengakses berbagai aplikasi sosial media, sambil mendengarkan lagu secara bersamaan.

Seiring dengan perkembangannya, sistem operasi android yang digunakan dalam smartphone memungkinkan pengguna untuk mengakses berbagai aplikasi dalam berbagai kategori. Salah satu kategori tersebut adalah aplikasi dalam kategori kesehatan dan kebugaran (health and fitness). Pada tahun 2012, aplikasi dalam bidang kesehatan dan kebugaran menempati ranking kelima dalam Top 10 Consumer Mobile Applications, dan pada tahun 2015, tercatat 1,4 miliar pengguna perangkat smartphone telah menggunakan aplikasi untuk kesehatan dan kebugaran. Dari jumlah 1,4 miliar pengguna aplikasi smartphone untuk kesehatan tersebut, 70 persen diantaranya adalah pengguna smartphone dengan sistem operasi android (Rao \& Krishna, 2014, p. 20).

Aplikasi dalam kategori kesehatan dan kebugaran (health and fitness) dapat memberikan informasi kepada penggunanya berkaitan dengan kesehatan dan kebugaran tanpa batasan tempat dan waktu, serta dapat membantu pengguna untuk mencapai target kehesatan dan kebugarannya (Higgins, 2016; Prins, Alsaqaf, Hettinga, van Berkel, \& Stomphorst, 2015; Rao \& Krishna, 2014). Dalam hal ini, aplikasi dalam kategori kesehatan dan kebugaran yang akan dikaji lebih lanjut adalah aplikasi yang digunakan oleh pengguna dalam membantu melakukan aktivitas fisik. Terdapat ratusan bahkan ribuan aplikasi dalam dalam kategori kesehatan dan kebugaran yang dapat membantu pengguna dalam melakukan aktivitas fisik.

Aplikasi kesehatan dan kebugaran dalam ponsel pintar dapat mempengaruhi seseorang dalam melakukan aktivitas fisik mengacu pada theory of planned behavior (Ajzen, 1991, pp. 179-199). Dalam teori tersebut, kebiasaan atau perilaku seorang individu dipengaruhi oleh tiga hal, yaitu: sikap terhadap perilaku atau kebiasaan yang akan dibentuk, hal serta manfaat yang dirasakan dari perilaku atau kebiasaan, serta subjektivitas dari masing-masing individu. Sikap terhadap perilaku atau kebiasaan yang dibentuk merupakan evaluasi dari masing-masing individu terhadap kebiasaan yang akan dibentuk. Sikap tersebut dapat bersifat positif maupun negatif. Hal yang dirasakan dari kebiasaan yang dibentuk berbentuk tingkat kesulitan dari kebiasaan yang dibentuk. Semakin tinggi tingkat kesulitan, berbanding terbalik dengan tingkat pembentukan kebiasaan, sedangkan subjektivitas individu 
berkaitan dengan persepsi individu terhadap kebia-saan atau perilaku yang akan dibentuk. Dalam hal ini, aplikasi kesehatan dan kebugaran yang digunakan dapat menumbuhkan sikap yang positif bagi pengguna dalam melakukan aktivitas fisik, serta dapat membantu pengguna mengurangi tingkat kesulitan dalam melakukan aktivitas fisik bagi pengguna yang belum mengetahui cara atau metode dalam melakukan aktivitas fisik (Dallinga, Mennes, Alpay, Bijwaard, \& Baart De La Faille-Deutekom, 2015; Ernsting et al., 2017; Litman et al., 2015).

Terdapat banyak aplikasi untuk membantu pengguna dalam melakukan aktivitas fisik, khususnya yang terdapat pada Playstore. Aplikasi tersebut dapat membantu pengguna dalam melakukan berbagai aktivitas fisik seperti berjalan, berlari, dan bersepeda. Aplikasi yang ada akan merekam/menyimpan riwayat aktivitas fisik yang dilakukan oleh pengguna melalui GPS, mencatat durasi, frekuensi, serta intensitas aktivitas fisik yang dilakukan. Beberapa aplikasi juga dapat membantu pengguna dalam menghitung kalori yang digunakan selama melakukan aktivitas fisik, menampilkan riwayat aktivitas fisik yang dilakukan dalam suatu periode tertentu serta dapat membagikan aktivitas fisik yang dilakukan dalam media sosial pengguna.

Berbagai manfaat yang positif dapat diterima dari adanya aplikasi dalam kategori kesehatan dan kebugaran khususnya aplikasi ponsel pintar dengan sistem operasi android. Perkembangan aplikasi tersebut juga sangat pesat, berikut juga dengan pengembangannya. Berbagai penelitian dan pengembangan tentang aplikasi kategori kesehatan dan kebugaran telah dilakukan dengan tujuan untuk memberikan kemudahan bagi masyarakat secara luas khususnya para pelaku olahraga dalam berbagai keperluan di bidang olahraga (Dolgener, Hensley, Marsh, \& Fjelstul, 1994; Ernsting et al., 2017; Litman et al., 2015). Namun, di salah satu sisi, berbagai kemudahan yang ada tersebut belum dioptimalkan oleh masyarakat secara umum, terlebih masyarakat olahraga yang sering berinteraksi dalam bidang olahraga. Berdasarkan survei yang dilakukan oleh peneliti pada tahun 2017, hanya sebagian kecil masyarakat olahraga di Daerah Istimewa Yogyakarta (DIY) yang menggunakan aplikasi kategori kesehatan dan kebugaran untuk membantu melaksanakan aktivitas fisik maupun keperluan lainya dalam bidang olahraga. Penggunaan aplikasi kesehatan dan kebugaran masih kalah jika dibandingkan dengan penggunaan aplikasi media sosial ataupun aplikasi berbentuk per- mainan. Dalam survei tersebut, perbandingan penggunaan aplikasi kesehatan dan kebugaran dengan aplikasi media sosial masih sangat jauh.

Berdasarkan hal tersebut, penelitian ini akan mengkaji persepsi serta minat masyarakat olahraga khususnya di DIY terhadap aplikasi ponsel pintar sistem operasi android dalam kategori kesehatan dan kebugaran. Tujuan penelitian ini adalah untuk memberikan gambaran tentang persepsi dan minat masyarakat olahraga di DIY terhadap aplikasi ponsel pintar sistem operasi android dalam kategori kesehatan dan kebugaran. Hasil penelitian diharapkan dapat bermanfaat sebagai gambaran dan proyeksi pasar pada pengembangan aplikasi ponsel pintar sistem operasi android dalam kategori kesehatan dan kebugaran. Selain itu, penelitian ini juga diharapkan dapat memberikan masukan pada kalangan masyarakat olahraga di DIY untuk menggalakkan penggunaan teknologi khususnya aplikasi ponsel pintar sistem operasi android dalam kategori kesehatan dan kebugaran untuk kemajuan bidang olahraga di DIY.

\section{METODE}

Penelitian ini merupakan penelitian deskriptif kuantitatif dengan tujuan untuk mengetahui persepsi dan minat masyarakat olahraga di Daerah Istimewa Yogyakarta terhadap aplikasi ponsel pintar sistem operasi android kategori kesehatan dan kebugaran. Jenis penelitian deskriptif akan memberikan paparan atau gambaran mengenai sesuatu hal, misalnya keadaan, kondisi, situasi, ataupun kegiatan (Arikunto, 2010, p.3). Metode yang digunakan adalah survei dengan teknik pengambilan data menggunakan kuisioner berbasis web. Skor yang diperoleh dari kuisioner dianalisis dengan teknik analisis deskriptif kuantitatif yang dituangkan dalam bentuk persentase.

Subjek penelitian ini adalah masyarakat olahraga di Daerah Istimewa Yogyakarta yang berusia 18-45 tahun, terdiri atas praktisi keolahragaan, akademisi di bidang olahraga kesehatan, serta masyarakat umum yang aktif berolahraga. Populasi tersebut diasumsikan bahwa masyarakat olahraga berusia 18-45 tahun merupakan masyarakat yang masih produktif untuk berolahraga dan ramah terhadap teknologi khususnya teknologi ponsel pintar bersistem operasi Android. Pemilihan sampel bersifat nonprobability sampling, dalam arti bahwa pengambilan sampel dalam penelitian ini tidak memberikan peluang yang sama bagi setiap populasi. Pengambilan sampel menggunakan teknik purposive sampling 
untuk melakukan seleksi sampel yang benarbenar sesuai bagi penelitian ini, yaitu pengguna ponsel pintar (smartphone) dengan sistem operasi Android dan merupakan masyarakat yang aktif berolahraga. Melalui survei, diperoleh 62 responden $(n=62)$ yang turut serta dalam penelitian ini.

Penelitian ini menggunakan instrumen berupa kuisioner berbasis web. Pernyataan berupa kuisioner disusun dengan menggunakan skala Likert. Dalam memberikan skor terhadap setiap pernyataan yang dijawab oleh responden, respon diwujudkan dengan skor: SS (Sangat Setuju) $=5$, $\mathrm{S}($ Setuju $)=4$, KS $($ Kurang Setuju $)=3$, TS $($ Tidak Setuju $)=2$, STS $($ Sangat Tidak Setuju $)=$ 1. Dalam proses persepsi dan minat tersebut, responden akan mengadakan penafsiran mengenai aplikasi ponsel pintar sistem operasi android kategori kesehatan dan kebugaran. Penelitian ini menggunakan 2 bagian kuisioner yang di dalamnya bertujuan untuk mengumpulkan data mengenai persepsi dan minat masyarakat olahraga tentang aplikasi ponsel pintar sistem operasi android kategori kesehatan dan kebugaran. Masing-masing item pernyataan telah diujicobakan untuk memenuhi syarat validitas dan reliabilitas instrumen.

Teknik analisis data dalam penelitian ini menggunakan teknik statistik deskriptif yang dituangkan dalam bentuk persentase (Sudijono, 2012, p.43).

$\mathrm{P}=\frac{f}{N} x 100 \%$

Keterangan:

$\mathrm{P}=$ persentase

$f=$ frekuensi yang dicari

$\mathrm{N}=$ jumlah total frekuensi.

Tabel 1. Norma Penilaian Persepsi dan Minat

\begin{tabular}{cl}
\hline Interval Skor & \multicolumn{1}{c}{ Kategori } \\
\hline$>\mathrm{M}+1,5 \mathrm{SD}$ & Baik Sekali \\
$\mathrm{M}+0,5 \mathrm{SD}(\mathrm{s} / \mathrm{d}) \mathrm{M}+1,5 \mathrm{SD}$ & Baik \\
$\mathrm{M}-0,5 \mathrm{SD}(\mathrm{s} / \mathrm{d}) \mathrm{M}+0,5 \mathrm{SD}$ & Cukup \\
$\mathrm{M}-1,5 \mathrm{SD}(\mathrm{s} / \mathrm{d}) \mathrm{M}+0,5 \mathrm{SD}$ & Kurang \\
$<\mathrm{M}-1,5 \mathrm{SD}$ & Kurang Sekali \\
\hline
\end{tabular}

Keterangan:

$\mathrm{M}=$ Mean/ rerata

$\mathrm{SD}=$ Standar Deviasi

Perolehan skor mentah dari kuisioner diubah menjadi hasil nilai standar menggunakan Mean (M) dan Standar Deviasi (SD) berskala lima.

\section{HASIL DAN PEMBAHASAN}

Data mengenai persepsi dan minat masyarakat olahraga di Daerah Istimewa Yogyakarta terhadap aplikasi ponsel pintar sistem operasi android kategori kesehatan dan kebugaran dideskripsikan untuk mempermudah penyajian hasil penelitian (Biddle, Markland, Gilbourne, Chatzisarantis, \& Sparkes, 2001; Nelson et al., 2017). Hasil analsis deskriptif data persepsi responden terhadap aplikasi ponsel pintar sistem operasi android kategori kesehatan dan kebugaran adalah Rerata atau mean $(85,9)$, Median (88), Modus (76), Standar Deviasi (16,2), skor maksimal (110) dan skor minimal (58). Data minat responden terhadap aplikasi ponsel pintar sistem operasi android kategori kesehatan dan kebugaran adalah Rerata atau mean $(92,6)$, Median (93), Modus (79), Standar Deviasi $(12,34)$, skor maksimal (117) dan skor minimal (65).

Data hasil tentang persepsi dan minat responden terhadap aplikasi ponsel pintar sistem operasi android kategori kesehatan dan kebugaran kemudian disajikan dalam perhitungan kategorial. Secara rinci, hasil penilaian melalui kuisioner akan disajikan Tabel 2.

Tabel 2. Perhitungan Kategorial Persepsi Responden

\begin{tabular}{lccc}
\hline \multicolumn{1}{c}{ Kategori } & Interval & $\mathrm{F}$ & $\%$ \\
\hline Baik Sekali & $x>110$ & 3 & 4,8 \\
Baik & $94<x \leq 110$ & 23 & 37,2 \\
Cukup & $78<x \leq 94$ & 14 & 22,6 \\
Kurang & $62<x \leq 78$ & 19 & 30,6 \\
Kurang Sekali & $x<62$ & 3 & 4,8 \\
\multicolumn{1}{c}{ Jumlah } & & 62 & 100 \\
\hline
\end{tabular}

Berdasarkan data Tabel 2, diketahui bahwa persepsi responden terhadap aplikasi ponsel pintar sistem operasi android kategori kesehatan dan kebugaran pada kategori Baik Sekali sebanyak 3 responden atau sebesar $4,8 \%$, Baik sebanyak 23 responden atau sebesar $37,2 \%$, Cukup sebanyak 14 responden atau sebesar 22,6\%, Kurang sebanyak 19 responden atau sebesar $30,6 \%$, dan Sangat Kurang sebanyak 3 responden atau sebesar $4,8 \%$.

Berdasarkan data tersebut, ditunjukkan bahwa persepsi responden terhadap aplikasi ponsel pintar sistem operasi android kategori kesehatan dan kebugaran bervariatif. Meskipun demikian, sebagian besar responden mempunyai persepsi yang positif terhadap aplikasi ponsel pintar dengan sistem operasi android kategori kesehatan dan kebugaran. Responden dengan persepsi da- 
Jurnal Keolahragaan 7 (1), 2019 - 38

Muhammad Sigit Antoni, S. Suharjana

lam kategori baik dan sangat baik cukup familier dengan aplikasi kebugaran dan kesehatan. Aplikasi yang dimaksud dalam hal ini adalah aplikasi yang dapat membantu melakukan aktivitas fisik seperti berlari, bersepeda, ataupun berbagai bentuk latihan lainnya.

Responden dengan persepsi kategori cukup berdasarkan data penelitian adalah sebesar $22,6 \%$. Hal tersebut menunjukkan bahwa terdapat sebagian responden yang beranggapan aplikasi ponsel pintar dengan sistem operasi android kategori kebugaran dan kesehatan merupakan hal positif dalam kehidupan sehari-hari, akan tetapi tidak familier dengan aplikasi tersebut. Para responden dalam kategori ini mengetahui bahwa aplikasi ponsel pintar dengan sistem operasi android kategori kebugaran dan kesehatan dapat membantu melakukan aktivitas fisik, tetapi merasa tidak akrab dengan aplikasi tersebut.

Sebesar masing-masing 30,6\% dan 4,8\% responden mempunyai persepsi kategori rendah dan sangat rendah terhadap aplikasi ponsel pintar sistem operasi android kategori kebugaran dan kesehatan. Hal tersebut menunjukkan bahwa masih terdapat lebih dari 35\% responden yang mempunyai persepsi negatif terhadap aplikasi ponsel pintar sistem operasi android katerogi kebugaran dan kesehatan. Para responden tersebut tidak memliki pengetahuan yang cukup tentang aplikasi yang ada serta beranggapan bahwa aplikasi tersebut tidak banyak membantu dalam melakukan aktivitas fisik, bahkan sebagian responden yang mempunyai persepsi kategori sangat rendah beranggapan bahwa aplikasi ponsel pintar sistem operasi android kategori kebu-garan dan kesehatan merupakan hal yang tidak penting.

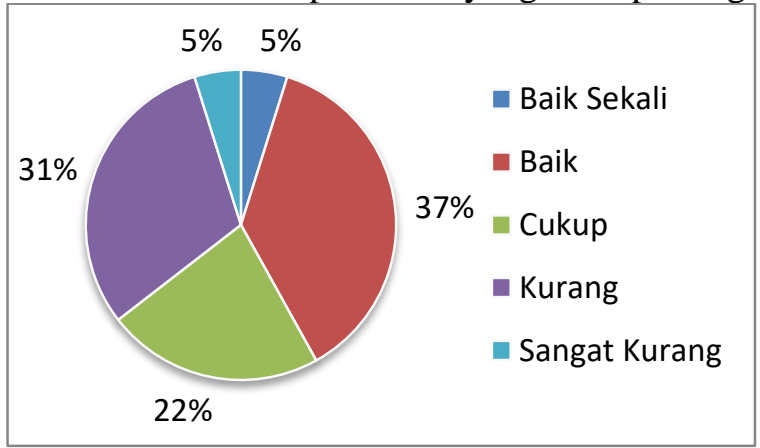

Gambar 1. Diagram Sebaran Data Persepsi Responden

Minat responden terhadap aplikasi ponsel pintar sistem operasi android kategori kesehatan dan kebugaran kemudian disajikan pada Tabel 3.
Tabel 3. Perhitungan Kategorial Minat Responden

\begin{tabular}{lccc}
\hline \multicolumn{1}{c}{ Kategori } & Interval & F & $\%$ \\
\hline Baik Sekali & $x>111$ & 8 & 12,9 \\
Baik & $99<x \leq 111$ & 27 & 43,6 \\
Cukup & $86<x \leq 99$ & 18 & 29 \\
Kurang & $74<x \leq 86$ & 7 & 11,3 \\
Kurang Sekali & $x<74$ & 2 & 3,2 \\
& & 62 & 100 \\
\hline
\end{tabular}

Berdasarkan data Tabel 3, diketahui bahwa minat responden terhadap aplikasi ponsel pintar sistem operasi android kategori kesehatan dan kebugaran pada kategori Baik Sekali sebanyak 8 responden atau sebesar 12,9\%, Baik sebanyak 27 responden atau sebesar 43,6\%, Cukup sebanyak 18 responden atau sebesar $29 \%$, Kurang sebanyak 7 responden atau sebesar $11,3 \%$, dan Sangat Kurang sebanyak 2 responden atau sebesar 3,2\%.

Data di atas menunjukkan bahwa sebagian besar responden mempunyai minat yang baik terhadap aplikasi ponsel pintar dengan sistem operasi android kategori kebugaran dan kesehatan. Sebesar masing-masing $43,6 \%$ dan $12,9 \%$ responden mempunyai minat dalam ketegori baik dan baik sekali. Para responden dalam kategori tersebut mempunyai keinginan untuk menggunakan aplikasi kategori kebugaran dan kesehatan. Selain itu, para responden dengan minat dalam kategori baik dan baik sekali juga mempunyai rasa ingin tahu yang besar serta mempunyai harapan aplikasi tersebut dapat meningkatkan aktivitas fisik, merekam aktivitas fisik yang telah dilakukan bahkan membantu dalam penyusunan program latihan.

Sejumlah 29\% responden mempunyai minat dalam kategori cukup terhadap aplikasi ponsel pintar sistem operasi android kategori kesehatan dan kebugaran. Responden tersebut mempunyai keinginan dan rasa ingin tahu pada aplikasi kategori kebugaran dan kesehatan, akan tetapi tidak disertai dengan keyakinan bahwa aplikasi tersebut dapat membantu dalam melakukan aktivitas fisik. Apabila responden dengan minat dalam kategori cukup akan menggunakan aplikasi ponsel pintar sistem operasi android kategori kesehatan dan kebugaran, para responden akan menggunakannya dengan alasan mengikuti trend semata atau hanya untuk sekedar eksis di media sosial, bukan dengan tujuan utama untuk membantu melakukan aktivitas fisik. Sejalan dengan penelitian yang dilakukan oleh Murnane, et all. (2015, p. 261), bahwa aplikasi kesehatan dalam ponsel pintar telah menjadi bagian dari sebuah trend, yang dapat menunjukkan 
eksistensi seseorang dalam interaksi sosial. Dalam kategori tersebut, responden dengan minat dalam kategori cukup terhadap aplikasi ponsel pintar sistem operasi android kategori kesehatan dan kebugaran menjadikan aplikasi tersebut sebagai sebuah trend dalam kehidupan seharihari.

Terdapat sekitar $14,5 \%$ responden mempunyai minat dalam kategori kurang dan sangat kurang terhadap aplikasi ponsel pintar sistem operasi android kategori kesehatan dan kebugaran. Para responden tersebut tidak mempunyai keinginan untuk menggunakan aplikasi aplikasi ponsel pintar sistem operasi android kategori kesehatan dan kebugaran. Keyakinan pada prosedur manual tanpa bantuan aplikasi masih melekat kuat pada responden. dengan minat dalam kategori kurang dan sangat kurang, bahkan responden dengan minat dalam kategori sangat kurang menyatakan tidak akan menggunakan aplikasi kategori kebugaran dan kesehatan.

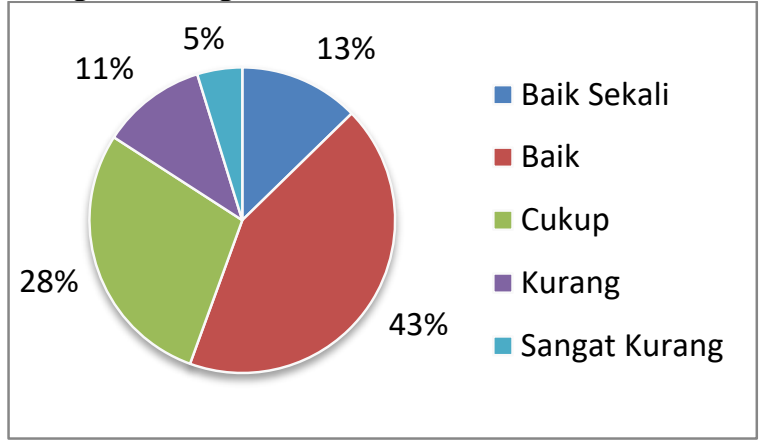

Gambar 1. Diagram Sebaran Data Motivasi Responden

Berdasarkan pada theory of planned behavior (Ajzen, 1991, pp. 179-211), aplikasi kesehatan dan kebugaran yang digunakan dapat menumbuhkan sikap yang positif bagi pengguna dalam melakukan aktivitas fisik, serta dapat membantu pengguna mengurangi tingkat kesulitan dalam melakukan aktivitas fisik bagi pengguna yang belum mengetahui cara atau metode dalam melakukan aktivitas fisik. Dalam hal ini, seseorang dengan literasi kesehatan yang baik akan menyikapi secara positif pula pada penggunaan aplikasi tersebut dalam melakukan aktivitas fisik (Ernsting et al., 2017). Selain itu, pengguna aplikasi tersebut juga akan menemukan kemudahan dalam pelaksanaan aktivtias fisik atau latihan yang dilakukan.

Persepsi dan minat yang negatif tidak secara langsung akan menimbulkan kesulitan bagi seseorang dalam melakukan aktivitas fisik atau latihan. Mempertahankan gaya hidup yang aktif ternyata sulit bagi sebagian banyak orang
(Marcus, Forsyth, Stone, Dubbert, McKenzie, Dunn, \& Blair, 2000). Selain itu, terdapat kesenjangan antara keingingan untuk sehat secara fisik dan betul-betul aktif untuk sehat (Rhodes \& Bruijn, 2013). Namun demikian hal tersebut membuka kemung-kinan lain bahwa seseorang yang melakukan aktivitas fisik atau latihan yang dibantu dengan aplikasi dalam kategori kebugaran dan kesehatan akan dapat lebih mudah untuk melaksanakan aktivitas fisik atau latihan serta pelaksanaan dalam langkah-langkah melakukan aktivitas fisik atau latihan.

Wang, Egelandsdal, Amdam, Almli, \& Oostindjer (2016) menyatakan bahwa penggunaan aplikasi dapat secara efektif memberikan peningkatan bagi penggunanya dalam melakukan berbagai aktivitas fisik dan latihan. Melalui aplikasi yang digunakan untuk membantu melakukan aktivitas fisik atau latihan, seseorang dapat meningkatkan intensitas latihan, mencapai berat badan yang ideal, serta mencatat dan mengetahui riwayat aktivitas fisik atau latihan yang telah dilakukan (Wang, Egelandsdal, Amdam, Almli, \& Oostindjer, 2016, p. 7)

Simamora (2002) mengemukakan bahwa persepsi merupakan proses yang terjadi di dalam diri seseorang dalam melakukan seleksi, mengorganisasi serta mengintepretasi suatu hal (stimulan) ke dalam suatu gambaran yang berarti dan menyeluruh. Persepsi dapat dipengaruhi oleh beberapa aspek, salah satunya adalah aspek seleksi perseptual. Dalam aspek seleksi perseptual, faktor personal dan stimulus memberikan pengaruh dalam pembentukan persepsi. Faktor personal berhubungan dengan pengalaman, kebutuhan, serta adaptasi, sedangkan faktor stimulus misalnya ukuran, tekstur, keunikan, komposisi, dan lain-lain.

Perbedaan persepsi responden dalam penelitian ini tidak terlepas dari pengaruh aspek seleksi perseptual masing-masing responden. Setiap individu pada dasarnya mempunyai pengalaman, kebutuhan serta proses adaptasi yang berbeda-beda, khususnya pada hal ini adalah tentang aplikasi ponsel pintar dengan sistem operasi android kategori kebugaran dan kesehatan. Seseorang dengan pengalaman yang baik, dapat memperoleh manfaat, menjadikan aplikasi kebugaran dan kesehatan sebagai kebutuhan serta dapat dengan muda beradaptasi dalam penggunaan aplikasi akan mampu memunculkan persepsi yang baik terhadap aplikasi ponsel pintar dengan sistem operasi android kategori kebugaran dan kesehatan. Faktor stimulan yang berasal dari aplikasi ponsel pintar dengan sistem operasi 
android kategori kebu-garan dan kesehatan juga mempengaruhi persepsi individu. Dalam penelitian ini, hal tersebut dapat berupa jenis aplikasi, ukuran dan keseuaian aplikasi, serta supporting system dari aplikasi yang digunakan.

Simamora (2002) juga menyebutkan bahwa terdapat aspek intepretasi yang dapat mempengaruhi persepsi seseorang. Dalam hal ini, intepretasi berhubungan dengan keselarasan antara harapan dan stimulus. Kedekatan intepretasi pada realitas bergantung pada kejelasan stimulus, pengalaman serta motivasi dan minat seseorang pada pembentukan persepsi. Berdasarkan hal tersebut, dapat menjadi perhatian bahwa munculnya persepsi yang beragam terhadap aplikasi ponsel pintar dengan sistem operasi android kategori kebugaran dan kesehatan tidak hanya dipengaruhi oleh faktor individu sebagai pengguna aplikasi, melainkan juga berasal dari aplikasi yang ada.

Ernsting, Dombrowski, Oedekoven, O'Sullivan, Kanzler, Kuhlmey, \& Gellert (2017) melakukan survei kepada pengguna ponsel dan menemukan bahwa usia, keadaan sosial ekonomi, literasi dan disparitas kesehatan mempengaruhi seseorang dalam menggunakan teknologi untuk menjaga kesehatan. Dalam hal ini, persepsi masyarakat khususnya masyarakat olahraga di DIY juga dipengaruhi oleh faktor usia, keadaan sosial ekonomi, literasi serta disparitas kesehatan. Dalam kategori usia yang masih produktif, seseorang akan lebih aktif untuk berinteraksi dengan teknologi dalam menjaga kesehatan. Begitu juga dengan keadaan sosial ekonomi, serta literasi. Seseorang dengan keadaan sosial ekonomi yang baik, didukung dengan literasi yang mencukupi tentang usaha dalam menjaga kesehatan dengan peran teknologi cenderung akan mempunyai persepsi yang baik pula terhadap teknologi dalam usaha menjaga kesehatannya.

Holland (Djaali, 2007, p.122) menyatakan bahwa minat merupakan kecenderungan hati yang tinggi terhadap sesuatu. Menurut Crow and Crow (Dimyati Mahmud, 2001, p.56), ada tiga faktor yang mendasari timbulnya minat seseorang yaitu: (1) faktor dorongan yang berasal dari dalam yang dapat berupa kebutuhan yang berhubungan dengan jasmani dan kejiwaan, (2) faktor motif sosial, yaitu kebutuhan untuk mendapatkan penghargaan dan lingkungan dimana seseorang berada, dan (3) faktor emosional, yaitu ukuran intensitas seseorang dalam menaruh perhatian terhadap sesuatu kegiatan atau obyek tertentu.
Berkaitan dengan minat seseorang terhadap aplikasi ponsel pintar dengan sistem operasi android kategori kebugaran dan kesehatan, baik minat yang positif maupun negatif berhubungan dengan beberapa faktor dorongan dari dalam, motif sosial, maupun emosional. Kebutuhan menjadi faktor mendasar dalam seseorang mempunyai minat terhadap aplikasi ponsel pintar dengan sistem operasi android kategori kebugaran dan kesehatan. Selain itu, lingkungan serta penghargaan bagi seseorang akan menimbulkan minat terhadap aplikasi ponsel pintar dengan sistem operasi android kategori kebugaran dan kesehatan. Intensitas seseorang dalam menggunakan aplikasi ponsel pintar dengan sistem operasi android kategori kebugaran dan kesehatan juga akan memberikan dampak pada minat seseorang pada aplikasi kebugaran dan kesehatan.

Sehubungan dengan persepsi dan minat masyarakat olahraga terhadap aplikasi ponsel pintar dengan sistem operasi android kategori kebugaran dan kesehatan, sebagian besar masyarakat mempunyai persepsi dan minat yang positif. Hal ini dapat menjadi peluang bagi pengembangan aplikasi. Dengan persepsi dan minat yang baik, maka pemanfaatan aplikasi ponsel pintar dengan sistem operasi android kategori kebugaran dan kesehatan dapat semakin baik. Hal tersebut juga dapat meningkatkan kualitas olahraga dan masyarakat olahraga khususnya di DIY. Di lain sisi, persepsi dan minat yang rendah menjadi sebuah tantangan dalam optimalisasi aplikasi ponsel pintar dengan sistem operasi android kategori kebugaran dan kesehatan. Pengambangan aplikasi hendaknya disesuaikan dengan kebutuhan masyarakat. Selain itu, karakteristik aplikasi juga sebaiknya disesuaikan dengan kondisi dan karakter yang ada pada masyarakat khususnya masyarakat olahraga.

\section{SIMPULAN}

Berdasarkan hasil penelitian serta pembahasan, dapat disimpulkan bahwa secara umum, persepsi dan minat para praktisi keolahragaan, akademisi di bidang olahraga kesehatan, serta masyarakat umum terhadap aplikasi ponsel pintar sistem operasi android kategori kesehatan dan kebugaran adalah baik. Persepsi responden terhadap aplikasi ponsel pintar sistem operasi android kategori kesehatan dan kebugaran pada kategori Baik Sekali sebesar 4,8\%, Baik sebesar $37,2 \%$, Cukup sebesar 22,6\%, Kurang sebesar $30,6 \%$, dan Sangat Kurang sebesar 4,8\%. Minat responden terhadap aplikasi ponsel pintar sistem 
operasi android kategori kesehatan dan kebugaran pada kategori Baik Sekali sebesar 12,9\%, Baik sebesar 43,6\%, Cukup sebesar 29\%, Kurang sebesar 11,3\%, dan Sangat Kurang sebesar 3,2\%.

\section{DAFTAR PUSTAKA}

Ajzen, I. (1991). The theory of planned behavior. Orgnizational Behavior and Human Decision Processes, 50, 179-211. https://doi.org/10.1016/07495978(91)90020-T

Arikunto, S. (2010). Prosedur penelitian: Suatu pendekatan praktik. Jakarta: Rineka Cipta.

Biddle, S. J. H., Markland, D., Gilbourne, D., Chatzisarantis, N. L. D., \& Sparkes, A. C. (2001). Research methods in sport and exercise psychology: Quantitative and qualitative issues. Journal of Sports Sciences, 19(10), 777-809. https://doi.org/10.1080/026404101317015 438

Dallinga, J. M., Mennes, M., Alpay, L., Bijwaard, H., \& Baart De La Faille-Deutekom, M. (2015). App use, physical activity and healthy lifestyle: A cross sectional study. BMC Public Health, 15(1), 1-9. https://doi.org/10.1186/s12889-015-21658

Dimyati Mahmud. (2001). Psikologi suatu pengantar. Yogyakarta: BPFE

Djaali. 2007. Psikologi pendidikan. Jakarta: Bumi Aksara

Dolgener, F. A., Hensley, L. D., Marsh, J. J., \& Fjelstul, J. K. (1994). Validation of the rockport fitness walking test in college males and females. Research Quarterly for Exercise and Sport, 65(2), 152-158. https://doi.org/10.1080/02701367.1994.10 607610

Ernsting, C., Dombrowski, S. U., Oedekoven, M., O'Sullivan, J. L., Kanzler, E., Kuhlmey, A., \& Gellert, P. (2017). Using smartphones and health apps to change and manage health behaviors: A populationbased survey. Journal of Medical Internet Research, 19(4), 1-12. https://doi.org/10.2196/jmir.6838

Higgins, J. P. (2016). Smartphone applications for patients' health and fitness. American Journal of Medicine, 129(1), 11-19. https://doi.org/10.1016/j.amjmed.2015.05. 038

Indonesia Investments. 2016. Indonesia is the
3rd-Largest Smartphone Market in the Asia Pacific, diakses dari https://www.indonesiainvestments.com/news/todaysheadlines/indonesia-is-the-3rd-largestsmartphone-market-in-the-asiapacific/item6777, pada 18 Januari 2017.

Litman, L., Rosen, Z., Spierer, D., WeinbergerLitman, S., Goldschein, A., \& Robinson, J. (2015). Mobile exercise apps and increased leisure time exercise activity: A moderated mediation analysis of the role of self-efficacy and barriers. Journal of Medical Internet Research, 17(8). https://doi.org/10.2196/jmir.4142

Marcus, B. H., Forsyth, L. H., Stone, E. J., Dubbert, P. M., McKenzie, T. L., Dunn, A. L., \& Blair, S. N. (2000). Physical activity behavior change: Issues in adoption and maintenance. Health Psychology, 19 (1, Suppl), $32-41$. http://dx.doi.org/10.1037/02786133.19.Suppl1.32

Murnane, Elizabeth L., et all. (2015). Mobile health apps: Adoption, adherence, and abandonment. UBICOMP/ISWC '15 ADJUNCT. http://dx.doi.org/10.1145/2800835.28009 43

Nelson, L., Pollard, H., Ames, R., Jarosz, B., Garbutt, P., \& Costa, C. Da. (2017). A descriptive study of sports chiropractors. Journal of Science and Medicine in Sport, $20,24$. https://doi.org/10.1016/j.jsams.2017.09.23 7

Prins, H., Alsaqaf, W., Hettinga, M., van Berkel, S., \& Stomphorst, J. (2015). Sports medical app to support the health and fitness of workers. International Journal on Advances in Life Sciences, 7(3-4), 7586.

Rao, V. S., \& Krishna, T. M. (2014). A design of mobile health for android applications. American Journal of Engineering Research (AJER), 03(06), 20-29.

Rhodes, R. E. \& Bruijn, G. (2013), How big is the physical activity intention-behaviour gap? A meta-analysis using the action control framework. Br J Health Psychol, 18: 296309. doi:10.1111/bjhp.12032

Safaat, N. H. (2014). Android - pemrograman aplikasi mobile smartphone dan tablet $p c$ 
Jurnal Keolahragaan 7 (1), 2019 - 42

Muhammad Sigit Antoni, S. Suharjana

berbasis android (revisi kedua). Bandung: Informatika.

Simamora, B. (2002). Panduan riset perilaku konsumen. Jakarta: Gramedia Pustaka Utama.

Statista. (2017). Mobile OS: Market share in Indonesia 2012-2017, diakses dari https://www.statista.com/statistics/262205 /market-share-held-by-mobile-operatingsystems-in-indonesia/, pada tanggal 18
Januari 2017.

Sudijono, A. (2012). Pengantar evaluasi pendidikan. Jakarta: PT Raja Grafindo Persada.

Wang, Q., Egelandsdal, B., Amdam, G. V, Almli, V. L., \& Oostindjer, M. (2016). Diet and physical activity apps: Perceived effectiveness by app users. JMIR MHealth and UHealth, 4(2), e33. https://doi.org/10.2196/mhealth.5114 